\title{
KEPEMIMPINAN TRANSFORMASIONAL DALAM PENINGKATAN MUTU PENDIDIKAN ANAK USIA DINI
}

\author{
Leni Nurmiyanti \\ STIT Islamic Village, Tangerang, Indonesia \\ Email : leninurmiyanti.stit@gmail.com \\ Bach Yunof Candra \\ STIT Islamic Village, Tangerang, Indonesia \\ Email : bach3candra@gmail.com
}

DOI: http://doi.org/10.33650/al-tanzim.v3i2.646

\begin{tabular}{l|l|l} 
Received: September 2019 & Revised: Oktober 2019 & Approved: November 2019
\end{tabular}

\begin{abstract}
:
Leadership is the peak of control in an organization, with the presence of a leader who can transform all activities optimally will facilitate the effectiveness and efficiency of all activities carried out together to achieve the agreed goals. This study tries to explain the advantages of transformational leadership in early childhood education management. Transformational leadership is the right choice for a leader to optimize his leadership in increasingly complex and dynamic management practices in the world of education. The method used in data collection is the method of library study (Library Research). The data is then deductively deducted and then integrated and adjusted to the concept of early childhood education. A discussion of results will be presented descriptively. Transformational leadership can improve the process and quality of early childhood education management by maintaining good relations with its members, motivating them to continue to develop, fostering a sense of belonging to the institution, motivating to fight for common interests rather than personal interests and maintaining high moral standards.
\end{abstract}

Key words : Leadership, Transformational, Quality of Education

\begin{abstract}
Abstrak
Kepemimpinan merupakan puncak kendali dalam suatu organisasi, dengan hadirnya seorang pemimpin yang mampu mentrasformasikan segala aktivitas dengan optimal akan memperlancar efektivitas dan efisiensi segala kegiatan yang dilaksanan bersama untuk mencapai tujuan yang telah disepakati bersama. Penelitian ini menyajikan tentang peningkatan mutu pendidikan anak usia dini melalui kepemimpinan trasformasional Kepemimpinan transformasional merupakan pilihan yang tepat bagi seorang pemimpin agar dapat mengoptimalkan kepemimpinannya dalam peraktik manajemen dunia pendidikan yang kian kompleks dan dinamis. Metode yang digunakan dalam pengumpulan data adalah metode studi pustaka (Library Research). Data-data tersebut kemudian direduksi secara deduktif untuk kemudian dipadukan dan disesuaikan dengan konsep pendidikan anak usia dini. Pembahasan hasil akan dipaparkan secara deskriptif. Kepemimpinan transformasional dapat meningkatkan proses dan mutu manajemen pendidikan anak usia dini dengan menjaga hubungan baik dengan para anggotanya, memotivasi mereka untuk terus berkembang, menumbuhkan rasa memiliki terhadap lembaga, memotivasi untuk memperjuangkan kepentingan bersama dari pada kepentingan pribadi dan menjaga standar moral yang tinggi.

Kata Kunci : Kepemimpinan, Transformasional, Mutu Pendidikan
\end{abstract}




\section{PENDAHULUAN}

Dalam mengembangkan kualitas serta efektifitas keorganisasian pada lembaga pendidikan anak usia dini, dibutuhkan sosok pemimpin dengan model kepemimpinan yang tepat, sehingga dapat melaksanakan tugasnya dengan baik, efektif serta efisien. Kepemimpinan dalam suatu lembaga pendidikan akan banyak berperan dalam lajunya perkembangan lembaga pendidikan yang dikelola (Bustamante \& Combs, 2011). Lembaga pendidikan yang kian maju dan modern sangat membutuhkan model kepemimpinan yang baik serta berkarakter (Wahid, 2018), sehingga mampu mengoptimalkan organisasi sesuai dengan asas-asas dari manajemen pendidikan yang berlaku (Syadzili, 2019). Kesuksesan suatu lembaga pendidikan tidak hanya menghasilkan output yang baik dalam produktifitasnya, namun juga prastasi dari semua element yang terlibat aktif di dalam keorgansiasian yang dikelola oleh seorang pemimpin.

Sosok pemimpin sangat berperan penting dalam sebuah organisasi (Moore, 2010). Banyak sekali teori yang membahas tentang gaya atau model kepemimpinan yang ideal di masa modern yang kian kompleks dan dinamis. Sosok pemimpin merupakan sosok yang dapat dianggap sebagai peran yang sangat penting dalam kehidupan untuk menegakkan keadilan serta kesejahteraan dan mengasilkan karya yang nyata. Pemimpin yang berkarakter tersebut tentunya akan menjadikan pemimpin kharismatik dan memiliki integritas dalam mengelola apa yang dipimpinnya, pemimpin yang berkarakter tentunya adalah sosok yang memiliki intelektualitas yang berbeda dengan manusia pada umumnya dan ia memiliki pengaruh dari pengetahuan yang dimilikinya. Kepiawaian dalam mengelola akan teruji, dari sejauh mana sang pemimpin memahami akan hakikat manusia dan kehidupan.

Untuk menciptakan generasi unggul dan berkualitas tentunya dibutuhkan lembaga pendidikan yang memiliki tujuan, visi dan misi. Berdasarkan hal tersebut, lembaga pendidikan dapat memanusiakan manusia serta mendidik para generasi dengan pondasi yang kuat. Kekuatan pondasi para generasi bangsa tentunya akan berhubungan dengan kekuatan karakter dan mental serta memfungsikan daya nalarnya secara optimal dalam proses pendidikannya. Lembaga pendidikan yang mampu menciptakan generasi unggul, tentunya membutuhkan pengelola dan pendidik yang handal dan prosefesional di bidangnya, sehingga manajemen pendidikan dapat bersinergi dalam menghasilkan produk dengan kualitas yang baik dan berdaya saing. Banyaknya model kepemimpinan membuat para pemimpin menentukan gaya apa yang hendak di gunakan agar lembaga yang dikelolanya dapat berjalan dan berkembang secara efektif dan efisien.

Penelitian ini ingin menjawab tentang; bagaimana meningkatkan mutu pendidikan anak usia dini melalui kepemimpinan trasformasional ? Semakin kompleksnya permasalahan di dunia pendidikan yang berkembang di era modern saat ini, dibutuhkan pilihan model kepemimpinan yang tepat untuk 
Al-Tanzim : Jurnal Manajemen Pendidikan Islam E-ISSN: 2549-5720 P-ISSN: 2549-3663

Vol. 03 No. 02 (2019) : 13-24

https:// ejournal.unuja.ac.id/index.php/al-tanzim

mengoptimalkan kerja manejerial di dunia pendidikan.

Tujuan penulisan artikel ini adalah untuk meningkatkan kualitas mutu manajemen pendidikan anak usia dini agar lebih dinamis dalam menjalankan proses pendidikan, dan siap menghadapi kompleksnya permasalahan di era modern. Kepemimpinan trasformasional kiranya dapat menjadi pilihan yang tepat dalam mengaktualkan efektifitas dan efisiensi menejerial di dalam peningkatan mutu manajemen pendidikan anak usia dini.

\section{Hakikat Kepemimpinan}

Pemimpin adalah seseorang yang dengan posisinya, kekuasaannya, atau prestisenya berusaha mengatur, mengarahkan, mengorganisir serta mengontrol usaha atau upaya orang lain untuk memprakarsai tingkah laku sosial. Sedangkan pengertian yang terbatas dari kata pemimpin ialah; seseorang yang dikuatkan dalam membimbing dan mengarahkan dengan bantuan kualitas dan potensi persuasifnya dan akseptansi/penerimaan secara sukarela oleh para pengikutnya (Robbins \& Judge, 2015). Keterkaitan pemimpin dan kepemimpinan bagaikan dua mata pisau yang tidak dapat dipisahkan, sebelum mengkaji lebih banyak terkait makna kepemimpinan, ada baiknya dipahami pula definisi formal dari seorang pemimpin. Pemimpin adalah sosok yang memiliki kepandaian, kecakapan dan kemampuan lebih dalam suatu bidang, kepandaian, kecakapan dan kemampuan tersebut menjadikan dirinya seseorang yang unggul dibandingnya.

Dalam mengelola dan memimpin organisasi, seorang pemimpin membutuhkan seni dalam memimpin yang disebut kepemimpinan. Kepemimpinan merupakan seni dalam memimpin yang dimiliki seseorang, dengan seni tersebut pemimpin mampu mengatur dan mengkoordinasikan secara sistematis dan terstruktur sehingga para anggota yang terlibat dapat dipengaruhi, pengaruh tersebut dapat menghantarkan suatu organisasi yang dipimpinnya menuju sasaran yang telah disepakati bersama. Danim (2010) mengemukakan bahwa kepemimpinan merupakan proses di mana sosok seorang pimpinan diharapkan akan memberi perintah atau pengaruh, bimbingan atau proses yang mengarahkan pekerjaan orang lain dalam pelaksanaannya untuk mencapai tujuan yang telah dipilih dan ditetapkan.

Kepemimpinan dapat dipahami sebagai permasalahan suatu pengaruh dalam relasi atau hubungan antara sosok seorang pemimpin dengan yang dipimpin. Kepemimpinan timbul dan berkembang berdasarkan hasil dari interaksi yang terjadi secara otomatis anatara sosok pemimpin dan individuindividu yang dipimpin memiliki relasi interpersonal (Kartono, 2011). Dalam kepemimpinan akan berhubungan dengan sekolompok orang yang memiliki tujuan yang sama agar tercapai apa yang diharapkan. Kesadaran manusia akan kehidupan berkelompok dan membangun sebuah kehidupan yang lebih baik membutuhkan aturan dan cara yang hendaknya diorganisir dengan baik dan benar. 
Pergerakan zaman menghantarkan manusia untuk menyesuaikan diri dengan kebutuhan zaman. Manusia modern yang terus bergerak dinamis mampu menghadapi kompleksitas kehidupan dalam bersosialisasi antar sesama manusia secara harmoni. Manusia modern merupakan organization man, sebab manusia modern selalu sibuk dalam mengorganisir sesuatu. Sedangkan "mengorganisir" itu artinya mengatur dan memimpin kerjasama antar bagianbagian (Whyte, 2013).

Pemimpin hendaknya pandai dalam mengelola organisasi yang dipimpinya, di mana dalam organisasi semua yang terlibat di dalamnya berproses dan bergerak untuk sampai pada tujuan dengan dilandasi oleh suatu kesadaran dan ketaatan pada pembagian tugas yang diberikan secara jelas dipahami hak dan wewenang sesuai dengan porsinya masing-masing, dengan memahami akan hal tersebut dapat memberikan stimulus kerelaan berkarya dan beraktivitas oleh seluruh anggota terkait.

Organisasi pendidikan terealisasi karena adanya suatu proses dari berbagai kegiatan seseorang atau sekelompok orang yang sesuai dengan fungsi dan tanggung jawabnya masing-masing, yang berkerja sama dalam mewujudkan tujuan yang telah ditentukan dan disepakati bersama. Pendidikan bermutu didapat melalui mekanisme yang holistic, memerlukan dukungan integrasi berbagai faktor yang memiliki pengaruh. Pemahaman holistik menurut Makmun, menekankan pada perilaku yang bertujuan (purposive) yang berarti bahwa aspek instrinsik yang ada dalam diri merupakan fakor utama dan penentu untuk melahirkan perilaku (Sagala, 2008).

Laju berkembanganya suatu organisasi akan sangat di pengaruhi oleh sosok pemimpin dalam kepemimpinannya, baik dan buruknya serta maju atau mundurnya suatu organisasi sering kali ditentukan oleh faktor gaya dan tipe dari kepemimpinan tersebut. Seorang pemimpin memiliki faktor yang sangat penting dalam memimpin, faktor tersebut adalah karakter yang dimiliki seorang pemimpin, seperti yang diungkapkan oleh Covey sebagaimana dikutip oleh Muhaimin (2015) tentang kegagalan seorang pemimpin, bahwa 90\% dari berbagai kegagalan kepemimpinan disebabkan oleh karakter seorang pemimpin.

Kepemimpinan yang merupakan sebuah proses, berusaha memberikan pengaruh terhadap anggota lainnya secara sosial, sehingga menjadikan tiaptiap anggota yang terlibat dapat melakukan perintah dan pekerjaan dengan loyalitas yang tinggi dalam mengaktualkan apa yang telah dikonsepkan dan direncakan oleh sang pemimpin. Kepemimpinan termasuk ke dalam ruang lingkup manajemen, dan manajemen memiliki makna yang lebih luas dari pada kepemimpinan (Siagian, 1989). Keterikatan tersebut akan berdampak pada efektifitas dan efisiensi dalam mengaktualkan apa yang telah dikonsepsikan bersama dalam optimalisasi manajerial disuatu lembaga pendidikan. 
Al-Tanzim : Jurnal Manajemen Pendidikan Islam E-ISSN: 2549-5720 P-ISSN: 2549-3663

Vol. 03 No. 02 (2019) : 13-24

https:// ejournal.unija.ac.id/ index.php/al-tanzim

Kepemimpinan merupakan kemampuan mempengaruhi suatu kelompok ke arah tujuan. Pendapat ini tidak jauh berbeda dengan pendapat para ahli lainnya, kemampuan seorang pemimpin dalam membuat metode atau cara untuk mengintervensi anggota sangat diperlukan, sehingga para anggotanya dapat bergerak bersama menuju arah yang telah disepakati (Robbin, 1991). Kepemimpinan adalah kemampuan membangkitkan untuk mengikuti dan mencapai tujuan yang diharapkan (Grisham, 2006).

Makna kepemimpinan jika ditinjau dari bahasa Arab, berasal dari kata al-ri'ayah, al-imarah, al-qiyadah, al-za'amah (Djuaeni, 2005). Yang jika diartikan memiliki arti kata yang sama atau persamaan kata yang diartikan dalam bahasa Indonesia sebagai kepemimpinan. Dalam sudut padang keisalaman peran kepemimpinan memiliki esensi dan peran yang sangat penting, sabda Nabi Muhammad Saw "Dari Abu Sa'id dari Abu Hurairah, Bahwa keduanya berkata, Rasullullah bersabda: Apabila tiga orang keluar berpergian, hendaklah mereka menjadikan salah satu sebagai pemimpin. (HR.Abu Dawud).

Berdasarkan Hadits tersebut dapat dijelasakan bahwa peran serta kepemimpinan menjadi suatu yang sangat penting, dikarena dalam berkumpulnya manusia dibutuhkan seseorang yang dijadikan penentu dan mengambil keputusan dalam perjalanannya agar dapat berjalan dengan baik dan dapat disepakati bersama apa yang hendak diinginkan, dengan kesepakatan bersama. Jika tidak ada yang dijadikan pemimpin, maka akan sulit menemukan titik temu dalam mengambil keputusan, karena setiap individu memiliki keinginan dan kepentingan yang berbeda, maka sosok pemimpin yang bijaksana akan mampu menyelaraskan perbedaan itu.

Kepemimpinan perlu menjadi perhatian utama karena melalui kepemimpinan yang baik diharapkan dapat terwujud lahirnya tenaga-tenaga yang berkualitas dalam berbagai bidang, baik sebagai pemikir, maupun sebagai pekerja (Atmodiwirio, 2000). Dunia pendidikan memiliki peran penting dalam menciptakan genarasi-generasi yang unggul dan berdaya guna. Oleh karenanya, kepemimpinanlah yang menjadi unjung tombak keberhasil dari menajemen pendidikannya. Dengan hadirnya generasi-generasi unggul dan mumpuni inilah segala tantangan dalam kehidupan modernisasi yang semakin berat dapat terjawab.

\section{Kepemimpinan dalam Aktivitas Manajerial Pendidikan Anak Usia Dini}

Kepemimpinan yang dilakukan oleh pemimpin akan memiliki dampak baik atau buruk dalam pengelolaan manajeman pendidikan di dalam oprasional kegiatan di suatu jenjang pendidikan. Efisiensi dan efektifitas kegiatan penyelengaraan pendidikan anak usia dini akan dapat mencapai tujuannya, manakala kepemimpinan yang dilakukan mendukung program pendidikan nasional yang telah ditetapkan oleh pemerintah. Dengan bersinerginya program-program yang dikelola oleh seorang pimpinan akan menghasilkan kepemimpinan yang baik. 
Kepemimpinan dapat efektif dan efisien jika dipimpin oleh seseorang yang memiliki daya nalar yang baik juga kepekaan hati dalam bertindak dan memahami segala kondisi dan situasi dalam keorganisasian kelompoknya. Pemimpin yang memiliki karekter dalam kepemimpinannya, tentunya akan memiliki keunikan dalam menata dan mengelola anggotanya. Seorang pemimpin yang memiliki pemahaman akan dirinya sendiri dan jujur akan segala tindakan serta perbuatannya, tentunya akan melahirkan kepercayaan dari anggota kelompoknya. Sehingga pengaruh yang diciptakan seorang pemimpin akan berdapak positif pada situasi kelompoknya, loyalitas pengikutnya, koumunikasi dan karakter kepemimpinannya.

Hubungan pemimpin dengan pengelolaan menjerial di dalam tata kelola merupakan hal yang sangat membutuhkan kreatiftas serta daya analisis yang tajam dalam mengurai segala dinamika dan persoalan yang ada. Seorang pemimpin umumnya memiliki sifat tidak puas dan selalu ingin membuat inovasi dan kebaruan dalam setiap kebijakannya untuk meningkatkan kinerja anggotanya, mereka memiliki keberanian dalam setiap tindakan yang dilakukan untuk pengambilan keputusan serta kebijakan.

Pada prinsipnya setiap manusia memiliki keberanian dan juga ketidak pusaan dalam kehidupannya, daya nalarnya terus bekerja dan melakukan pergerakan. Pergerakan tersebut yang membuat manusia akan selalu mengingat sesuatu yang baru didalam kehidupannya. Keberanian dan ketidak puasan adalah kebutuhan kita hari ini (Danim, 2010). Maka semakin manusia produktif dalam kehidupannya, tentunya akan semakin meningkatkan potensi dirinya secara baik.

Suatu proses ataupun kerangka kerja yang melibatkan pembimbingan dan pengarahan pada suatu kelompok orang-orang ke arah tujuan-tujuan organisasional yang ditetapkan atau maksud-maksud yang nyata disebut manajemen (Terry \& Winardi, 2009). Fatah sebagaimana dikutip (Amtu, 2013) berpendapat bahwa; manejemen adalah proses memimpin perencanaan, pengorganisasian dan pengendalian upaya organisasi dengan segala aspek yang dimiliki agar tujuan organisasi tercapai secara efektif dan efisien. manajemen yang tepat akan membuat terwujudnya tujuan perusahan menjadi mudah dicapai baik oleh karyawan ataupun masyarakat. Manajemen akan meningkatkan daya guna dan hasil guna unsur-unsur yang ada di dalamnya.

Dalam mengoptimalisasikan manajemen ataupun pengelolaan perlu komponen-komponen yang terintegrasi, yang tidak terpisahkan dari proses yang dilakukan dengan proses yang lainnya yang saling berkaitan. Manajemen yang dipahami sebagai proses kerja sama sekelompok orang dengan menggunakan sumber daya yang organisasi dimiliki, demi tercapainya tujuan yang telah ditetapkan 
Al-Tanzim : Jurnal Manajemen Pendidikan Islam E-ISSN: 2549-5720 P-ISSN: 2549-3663

Vol. 03 No. 02 (2019) : 13-24

https:// ejournal.unuja.ac.id/index.php/al-tanzim

Pengelolaan manajemen memiliki beberapa unsur yang penting untuk mengefektifkan fungsi manjemen tersebut, unsur-unsur tersebut terdiri dari: Man, Money, Method, Mechines, Materialis and market, atau disingkat 6M. Manajemen adalah ilmu dan seni dalam mengatur prospek penggunaan sumber daya yang dimiliki, baik manusia ataupun yang lainnya, secara efektif dan efisien demi tercapainya suatu tujuan tertentu (Amtu, 2013).

Untuk menghasilkan kualitas lulusan yang bermutu dalam dunia pendidikan anak usia dini, maka pengelolaan manajemen pendidikan anak usia dini perlu menjadi perhatian yang sangat penting bagi kepala sekolah sebagai pimpinan sekolah. Pendidikan anak usia dini merupakan wadah yang sangat fundamental dalam pendidikan anak, dalam memberikan dan membentuk kerangka dasar yang mendukung berkembangnya dasar-dasar pengetahuan, sikap dan keterampilan pada anak (Mursid, 2015).

Pendidikan anak usia dini merupakan upaya pemberian stimulus, bimbingan, dan asuhan dalam kegiatan pembelajaran yang diharapkan akan menghasilkan kemampuan dan keterampilan pada anak (Nurani Sujiono, 2013). Pendidikan anak usia dini merupakan bentuk penyelenggaraan pendidikan yang menitik beratakan pada peletakan dasar tumbuh dan berkembangnya fisik yang mengkoordinasikan motorik halus dan kasar, kecerdasan daya pikir, daya cipta, emosi, spiritual, yang terwujud dalam sikap prilaku yang beragama, dalam bahasa dan komunikasi, sesuai dengan keunikan tahap-tahap perkembangan yang dilalui dan dialami oleh anak (Mursid, 2015). Pendidikan anak usia dini dapat diartikan juga sebagai salah satu bentuk penyelenggaraan pendidikan yang tertuju pada peletakan dasar pertumbuhan dan perkembangan, baik secara koordinasi motorik, kecerdasam emosi dan kecerdasan jamak (multiple intelligences) (Suyadi, 2013).

Pada hakikatnya pendidikan anak usia dini adalah pendidikan yang terselenggara dengan tujuan untuk memfasilitasikan dan menstimulus pertumbuhan dan perkembangan anak secara menyeluruh serta menitikberatan tujuannya pada perkembangan kepribadian anak (Suyadi, 2013). Keterlibatan pemimpin dalam kepemimpinannya yang produktif tentunya akan mendorong pergerakan kemajuan manajemen suatu lembaga pendidikan anak usia dini yang dikelolanya.

\section{KEPEMIMPINAN TRANSFORMASIONAL DAN PENINGKATAN MUTU PENDIDIKAN ANAK USIA DINI}

Dalam rangka menghasilkan mutu pendidikan pada pendidikan anak usia dini, maka pengelolaan manajemen pendidikan anak usia dini perlu menjadi perhatian yang sangat penting bagi kepala sekolah sebagai pimpinan sekolah. Pendidikan anak usia dini merupakan wadah yang sangat fundamental dalam pendidikan anak, dalam memberikan dan membentuk kerangka dasar yang mendukung berkembangnya dasar-dasar pengetahuan, sikap dan keterampilan pada anak (Mursid, 2015). 
Pada hakikatnya pendidikan anak usia dini adalah pendidikan yang terselenggara dengan tujuan untuk memfasilitasikan dan menstimulus pertumbuhan dan perkembangan anak secara menyeluruh serta menitikberatan tujuannya pada perkembangan kepribadian anak (Suyadi, 2013). Maka hubungan kepemimpinan dengan manajemen pendidikan anak usia dini, tentunya tidak dapat dipisahkan atau berjalan sendiri-sendiri. Keterlibatan pemimpin dalam kepemimpinannya yang produktif tentunya akan mendorong pergerakan kemajuan manajemen suatu lembaga pendidikan anak usia dini yang dikelolanya. Ruh pemimpin akan mendominasi lajunya efektifitas dan efisiensi kinerja para anggotanya.

Kepemimpinan transformasional merupakan kepemimpinan yang memiliki kesadaran yang tinggi tentang emosional, manajemen diri, kesadaran sosial dalam mengelola hubungan kerja. Pola perilaku kepemimpnan trasnformasional diharapkan memberi pengaruh positif terhadap anggotanya dalam membentuk nilai-nilai dan keyakinan tercapainya tujuan organisasi. Kepemimpinan transfomasional merupakan usaha yang dilakukan oleh kepala sekolah dalam mengatur tata kelola lembaga pendidikan yang dipimpinnya, dengan melibatkan dan mengarahkan pandangan anggotanya untuk melampaui kepentingan diri sendiri, dan menuju kepentingan bersama.

Kepala sekolah tansformasional dapat membuat seseorang bertindak atas nama kepentingan kolektif yang disepakati sehingga peningkatan mutu manajemen Pendidikan Anak Usia Dini dapat dilakukan secara dinamis. Kesadaran akan pentinganya bersama-sama menjaga dan meningkatkan proses yang menghasilkan output pendidikan yang lebih baik sesuai dengan tuntutan zaman. Pendekatan multidisiplin dapat memberikan hasil yang maksimal untuk pengembangan karakter (Baharun, 2017), terutama dalam kepemimpinan transformasional pada pendidikan anak usia dini, karena pendidikan usia dini adalah proses pembentukan karakter pertama dalam dunia pendidikan formal.

Segala yang diusahakan oleh model kepemimpinan transformasional dalam meningkatkan mutu pendidikan pada jenjang pandidikan anak usai dini, merupakan usaha yang dilakukan kepala sekolah dalam menjaga keseimbangan dan keselarasan hubungan antara para pendidik, tenaga kependidikkan, peserta didik dan wali peserta didik. Kesadaran yang tinggi akan menjaga standar moral yang tinggi, sehingga mampu mentransformasikan dan mempengaruhi sikap, tindakan, nilai-nilai yang lebih baik dalam diri para anggotanya.

Kepemimpinan transformasional akan membangkitkan emosi anggota organisasi, khususnya pada lembaga pendidikan anak usia dini, sehingga mempunyai rasa memiliki yang tinggi terhadap lembaga, dan memotivasi mereka bertindak di luar kerangka yang digambarkan sebagai hubungan pertukaran. Kepemimpinan transformasional adalah gaya kepemimpinan yang memiliki visi dan misi yang baik, retoris dan keterampilan menajemen untuk 
Al-Tanzim : Jurnal Manajemen Pendidikan Islam E-ISSN: 2549-5720 P-ISSN: 2549-3663

Vol. 03 No. 02 (2019) : 13-24

https:// ejournal.unuja.ac.id/index.php/al-tanzim

mengembangkan hubungan dan ikatan emosional yang kuat dengan para anggota. Kepemimpinan transformasional memotivasi para anggota untuk bekerja demi mencapai tujuan yang melampaui kepentingan pribadi, sehingga melaksanakan proses pendidikan sebaik-baiknya yang dapat meningkatkan mutu manajemen lembaga.

Upaya yang dilakukan kepala sekolah dengan mengerakkan para pengikutnya untuk berperan aktif, merupakan bagian dari cara meningkatkan mutu pendidikan. Peningkatan mutu pendidikan, akan dapat optimal jika semua yang ada mempunyai rasa memiliki serta kesadaran akan tangung jawab dan tugas yang telah diembannya dan diamanahkan padanya. Sallis (2011) menjelaskan bahwa mutu adalah kualitas yang memberikan kepuasan yang melampaui keinginan dan kebutuhan seseorang atau sekelompok orang.

Peningkatan mutu pendidikan tentunya akan melibatkan berbagai macam faktor yang terlibat di dalamnya. Model kepemimpinan transformasional merupakan salah satu cara dalam mendukung peningkatan mutu pendidikan dalam perkembangan zaman yang kian maju. Pola pikir yang kian berkembang dangan tuntutan zamannya, membutuhkan pemimpin yang arif serta bijaksana dan mampu memberikan motivasi secara aktif dalam meningkatkan kinerja anggotanya. Kepemimpinan transformasional adalah salah satu solusi dalam usaha meningkatkan mutu pendidikan anak usia dini untuk menghasilkan generasi yang unggul dalam mengoptimalisasikan masa emas pada anak generasi bangsa.

Terdapat enam hal mengapa kepemimpinan transformasional penting bagi sebuah organisasi, yaitu : (1) Meningkatkan kinerja organisasi secara signifikan, (2) Memiliki hubungan dengan orientasi pemasaran jangka panjang dan kepuasan pelanggan secara positif, (3) Komitmen yang lebih tinggi para anggotanya terhadap organisasi akan bangkit, (4) Kepercayaan pekerja pada menajemen dan perilaku keseharian organisasi akan meningkat, (5) Kepercayaan pekerja kepada pemimpin akan meningkat, (6) Stress para pekerja akan berkurang dan kesejahteraan akan meningkat.

Implemtasi gaya kepemimpinan transformasional dalam organisasi pendidikan perlu memperhatikan hal-hal berikut: (1) Mengacu pada nilai-nilai agama yang ada dalam organisasi dan bahkan suatu Negara, (2) Disesuaikan dengan nilai-nilai yang terkandung dalam sistem organisasi, (3) Menggali budaya yang ada dalam organisasi, (4) Sistem pendidikan merupakan suatu sub sistem maka harus memperhatikan sistem yang lebih besar yang berada diatasnya seperti sistem Negara. 


\section{KESIMPULAN}

Kepemimpinan transformasional dapat meningkatkan mutu manajemen pendidikan anak usia dini. Selain itu, kepemimpinan tranformasional dapat mengoptimalisaisikan proses pendidikan anak usia dini. Optimalisasi dalam proses pendidikan anak usia dini terjadi ketika seorang pemimpin lembaga pendidikan anak usia dini menjaga hubungan baik dengan para anggotanya, memotivasi mereka untuk terus berkembang, menumbuhkan rasa memiliki terhadap lembaga, memotivasi untuk memperjuangkan kepentingan bersama dari pada kepentingan pribadi dan menjaga standar moral yang tinggi, sehingga segala kegiatan dan aktfitas pendidikan yang berlangsung di dalam proses pendidikan anak usia dini berjalan secara efektifi dan efsiensi. Kepemimpinan tranformasional dengan standar moral serta etika yang tinggi dapat menginspirasi serta memberikan keteladanan yang baik, sehingga segenap pendidik, tenaga kependidikan serta peserta didik dapat meneladani dan termotivasi, juga terilhami dengan apa yang dilakukan oleh pemimpin.

Kepemimpinan tranformasional merupakan salah satu solusi yang dapat disuguhkan dalam mengefektifkan manajemen pendidikan anak usia dini atau jenjang pendidikan lainnya. Kelemahan dari kepemimpinan tranformasional adalah ketika seorang pemimpin mengunakan model ini, namun secara katareristik, kepribadiannya belum memiliki standar etika dan moral yang tinggi, hal ini akan dapat menghabat proses kepemimpinannya, dikarenakan kepribadainnya dan pengetahuannya tidak bersinergi dengan baik. Maka teori ini dapat digunakan secara efektif, manakala seorang pemimpinan telah dapat mengenal dirinya secara baik dan telah berusaha mengoptimalisasikan kecerdasan jamak dalam dirinya. 
Al-Tanzim : Jurnal Manajemen Pendidikan Islam E-ISSN: 2549-5720 P-ISSN: 2549-3663

Vol. 03 No. 02 (2019) : 13-24 bttps:// ejournal.unija.ac.id/ index.php/al-tanzim

\section{DAFTAR PUSTAKA}

Amtu, O. (2013). Manajemen Pendidikan di Era Otonomi Daerah: Konsep, Strategi, dan Implementasi. Bandung: Alfabeta.

Atmodiwirio, S. (2000). Manajemen Pendidikan Indonesia. Jakarta: Ardadizya Jaya.

Baharun, H. (2017). Total Moral Quality: A New Approach for Character Education in Pesantren. Ulumuna, 21(1), 57-80.

Bustamante, R., \& Combs, J. P. (2011). Research Courses in Education Leadership Programs: Relevance in an Era of Accountability. International Journal of Education Policy E Leadership, 6(3), 1-11.

Danim, S. (2010). Kepemimpinan Pendidikan. Bandung: Alfabeta.

Djuaeni, M. N. (2005). Kamus Kontemporer Indonesia-Arab Istilah Politik-Ekonomi. Bandung: Mizan.

Grisham, T. (2006). Cross-Cultural Leadership in Construction. Proceedings of the International Conference on Construction Culture, Innovation, and Management, Dubai, UAE, 26-29.

Kartono, K. (2011). Pemimpin dan Kepemimpinan. Jakarta: PT Rajawali Grafindo Persada.

Moore, L. L., Grabsch, D. K., \& Rotter, C. (2010). Using Achievement Motivation Theory to Explain Student Participation in a Residential Leadership Learning Community. Journal of Leadership Education, 9(2), 22-34. https://doi.org/10.12806/V9/I2/RF2

Muhaimin. (2015). Manajemen Pendidikan (Aplikasinya dalam Penyusunan Rencana Pengembangan Sekolah/Madrasah). Jakarta: Kencana.

Mursid, B. (2015). Pengembangan Pembelajaran PAUD. Bandung: PT Remaja Rosdakarya.

Nurani Sujiono, Y. (2013). Konsep Dasar PAUD. Jakarta: Indeks.

Robbin, S. P. (1991). Management Principles: A Contemporary Edition for Africa. New Jersey: Prentice-Hall.

Robbins, S. P., \& Judge, T. A. (2015). Perilaku Organisasi. Jakarta: Salemba Empat.

Sagala, S. (2008). Budaya dan Reinventing Organisasi Pendidikan: Pemberdayaan Organisasi Pendidikan ke Arah yang Lebih Profesional dan Dinamis di Provinsi, Kabupaten/Kota, dan Satuan Pendidikan. Bandung: Alfabeta.

Sallis, E. (2011). Total Quality Management. Yogyakarta: IRCiSoD. 
Siagian, S. P. (1989). Fungsi-fungsi Manajerial. Jakarta: Bina Aksara.

Suyadi. (2013). Konsep Dasar PAUD. Bandung: PT Remaja Rosdakarya.

Syadzili, M. F. R. (2019). Polarisasi Tahapan Kepemimpinan Transformatif Pendidikan Islam. Al-Tanzim : Jurnal Manajemen Pendidikan Islam, 3(1), 5581.

Terry, G. R., \& Winardi. (2009). Asas-Asas Manajemen. Jakarta: Alumni.

Wahid, A. H., Muali, C., \& Rafikah, K. (2018). Pengembangan Karakter Guru dalam Menghadapi Demoralisasi Siswa Perspektif Teori Dramaturgi. Jurnal Mudarrisuna, 8(1), 102-126.

Whyte, W. H. (2013). The Organization Man. Garden City: University of Pennsylvania Press. 